\title{
THE AGE OF THE LAGUNA HULE EXPLOSION CRATER, COSTA RICA, AND THE TIMING OF SUBSEQUENT TEPHRA ERUPTIONS: EVIDENCE FROM LAKE SEDIMENTS
}

\author{
Sally P. Horn \\ Department of Geography, University of Tennessee, Knoxville, Tennessee 37996 \\ U.S.A.
}

(Recibido 7/12/1999; Aceptado 29/3/2000)

\begin{abstract}
The eruption of the Laguna Hule explosion crater formed the depression now occupied by Laguna Hule (10 $\left.17^{\circ} 50^{\prime \prime} \mathrm{N}, 84^{\circ} 12^{\prime} 43^{\prime \prime}\right)$ and two other lakes, and apparently deposited volcanic tephra in nearby Laguna María Aguilar (10¹8'09" N, 84 $\left.{ }^{\circ} 11^{\prime} 24^{\prime \prime}\right)$. AMS radiocarbon dates on leaves and small wood fragments in sediment cores from Laguna Hule and Laguna María Aguilar confirm and extend the results of prior radiocarbon dating of wood in volcanic deposits from the Hule explosion crater and Volcán Congo. Taken together, the new and prior results indicate that the Hule maar formed between 2950 and 2471 calibrated (cal.) years B.P. Lake sediments began to accumulate near the present northeastern peninsula in Laguna Hule within a few centuries of the formation of the maar. At least twice since the formation of the lake, a volcanic eruption within or near the crater deposited tephra in the lake basin that was preserved as a thin layer in the lake sediments. This tephra possibly originated from an intramaaric subsidiary cone. Extrapolating from sedimentation rates calculated from two AMS radiocarbon dates on leaves in Hule core sediments suggests that the earlier eruption occurred about 1740 cal. years B.P. and the more recent eruption occurred about $670 \mathrm{cal}$. years B.P.
\end{abstract}

\begin{abstract}
RESUMEN: La erupción del cráter de explosión de la Laguna Hule formó la depressión en que existe hoy día la Laguna Hule ( $10^{\circ} 17{ }^{\prime} 50^{\prime}$ N, $\left.84^{\circ} 12^{\prime} 43^{\prime \prime}\right)$ y dos otras lagunas, y aparentamente depositó tefras en la cercana Laguna María Aguilar (10¹8'09” N, 84¹1'24”). Las fechas radiocarbónicas tipo AMS sobre hojas y pequeños fragmentos de madera en núcleos de sedimentos de la Laguna Hule y la Laguna María Aguilar confirman y extenden los resultados de dataciones radiocarbónicas previas sobre madera en depósitos volcánicos del maar de Hule y del Volcán Congo. En combinación, los nuevos y previos resultados indican que el mar de Hule se formó entre 2950 y 2471 años calibrados (cal.) A.P. La acumulación de sedimentos lacustres empezó entre unos siglos en un sitio al lado de la península actual al lado noroeste de la laguna. Por lo menos dos veces después de la formación de la laguna, erupciónes volcánicas entre o cerca del crater depositaron tefras en la laguna que fueron preservadas como capas finas en los sedimentos lacustres. Estas tefras posiblemente se originaron de un cono subsidiario intramaárico. Extrapolando las tasas de sedimentación calculadas de dos dataciones tipo AMS para hojas en sedimentos de los núcleos de la Laguna Hule sugiere que la primera erupción occurió aproximadamente 1740 años cal. A.P., y que la erupción más reciente occurió aproximadamente 670 años cal. A.P.
\end{abstract}

\section{INTRODUCTION}

Laguna Hule $\left(10^{\circ} 17^{\prime} 50^{\prime \prime} \mathrm{N}, 84^{\circ} 12^{\prime} 43^{\prime \prime}\right)$, located $11 \mathrm{~km}$ north of Volcán Poás in the Area Conservación de la Cordillera Volcánica Central, is one of the largest natural lakes in Costa Rica, with a surface area of approximately 55 ha (Umaña et al., 1999; Haberyan \& Horn, in press; Figs. 1 and 2). Laguna Hule and two smaller lakes occupy the floor of a volcanic depression that Soto (1990) determined to be an explosion crater of the maar-type. A pyroclastic cone and associated lava flow in the center of the crater separates Laguna Hule from Laguna Congo (15 ha) and the much smaller Laguna Bosque Alegre (0.6 ha, unofficial name; Horn \& Haberyan, 1993). All lakes are at $740 \mathrm{~m}$ elevation (Fig.1).

The Hule maar lies within a zone of apparent crustal weakness that begins at Volcán Poás and extends northward through the composite cone of Volcán Congo and the Hule maar to a second maar occupied by 


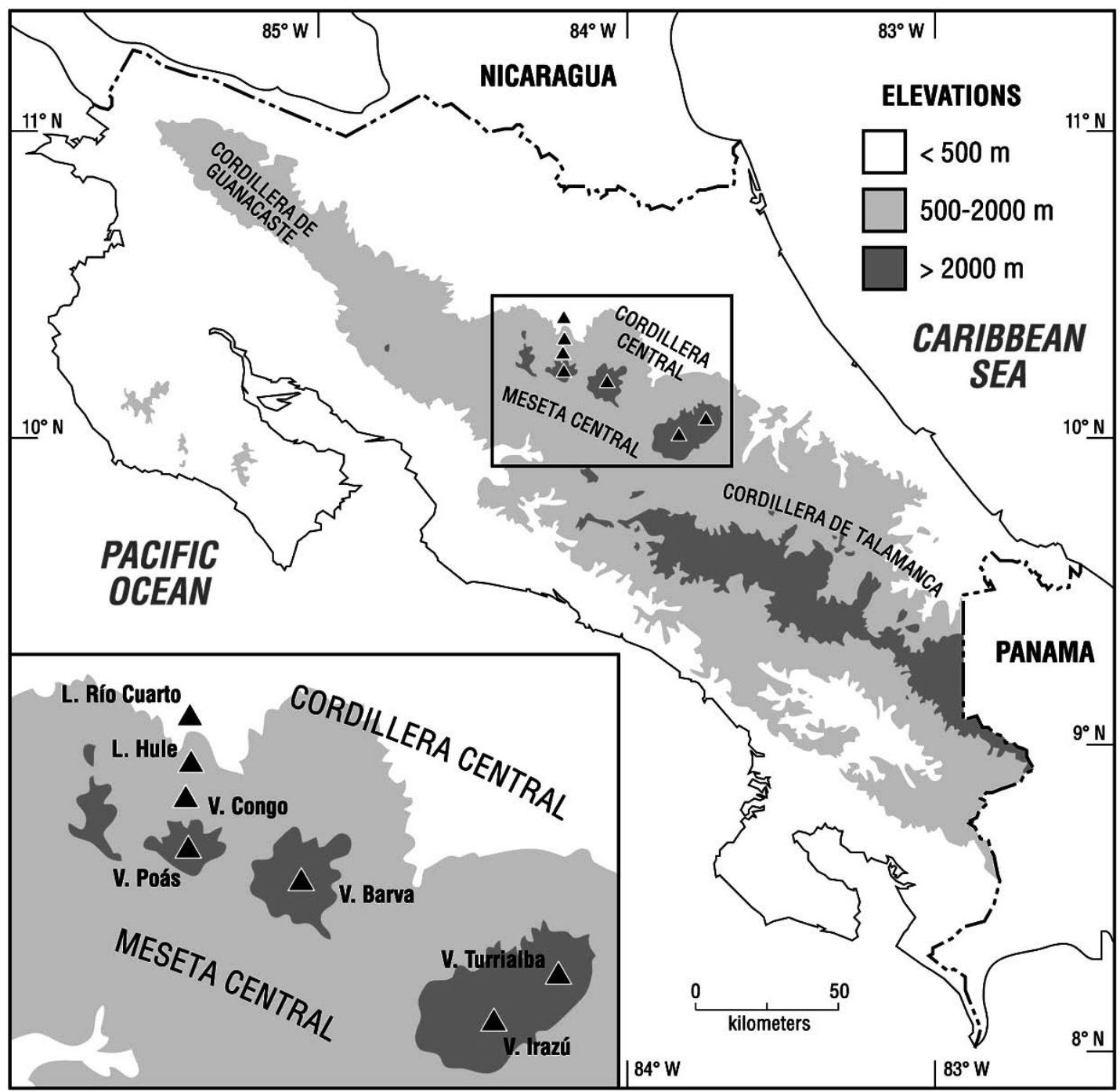

Fig. 1: Location of the Laguna Hule maar and other volcanic features of Cordillera Central of Costa Rica. The Poás volcanic alignment extends northward from Volcán Poás through Volcán Congo, the Laguna Hule maar, and the Laguna Río Cuarto maar.

Laguna Río Cuarto (Alvarado, 1989; Soto, 1990; Figs. 1 and 2). Malvassi et al. (1990) have referred to this zone as the Poás volcanic alignment, and they as well as others have investigated its eruptive history. Previous work has focused on the description and dating of volcanic deposits exposed in roadcuts and crater walls. In this paper I describe evidence from lake sediment cores that complements and extends existing radiocarbon evidence for the age of the Hule explosion crater, and provides the first estimates on the timing of subsequent tephra eruptions recorded in the Laguna Hule lake sediments.

As noted by Melson et al. (1988), topographically the Hule maar appears to be carved into the north slope of Volcán Congo, which would suggest that its formation postdates the eruption that formed the principal cone of Volcán Congo. Melson et al. (1988) 


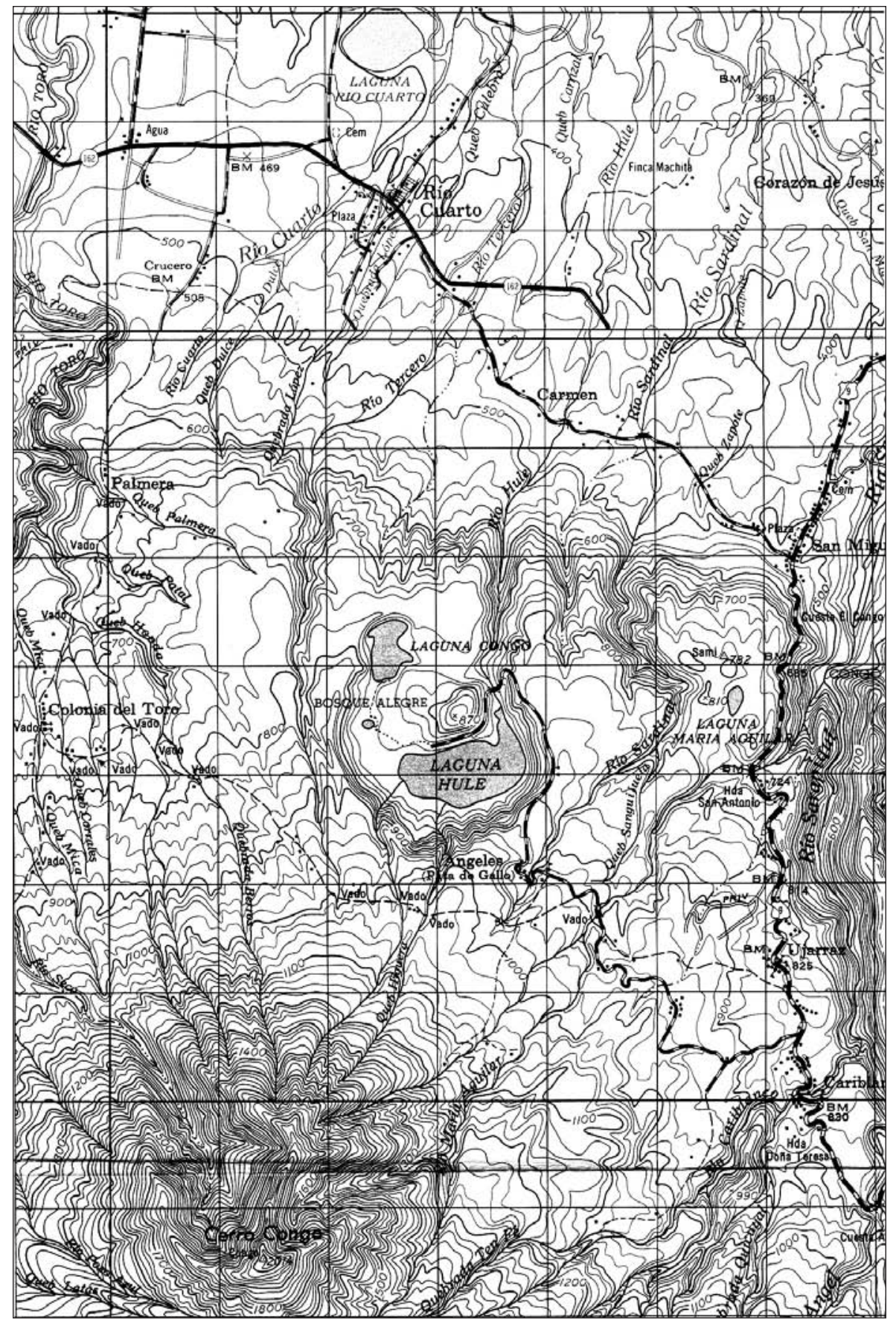

Fig. 2: Portion of the Poás and Río Cuarto sheets of the 1:50,000 scale topographic map series published by the Instituto Geográfico Nacional, showing Volcán Congo, Lagunas Hule, Bosque Alegre, and Congo in the Hule explosion crater, Laguna María Aguilar, and Laguna Río Cuarto. 
were able to confirm this interpretation through examination of volcanic deposits in road cuts between Volcán Congo and the Hule crater. Pyroclastic deposits from Volcán Congo were found to surround the Hule maar and to be overlain near the crater with finely stratified ash and coarser tephra from the explosion that formed the Hule maar. At a cut in the Quebrada Higuera, they found Hule tephra resting discordantly on a wood-bearing pyroclastic flow from Volcán Congo. Radiocarbon dating of a carbonized branch or small tree recovered from the Congo pyroclastics yielded a date of $5140 \pm 110{ }^{14} \mathrm{C}$ yr B.P. This result provided a maximum age for the formation of the Hule maar. Based on this date, and on the state of soil development at Laguna Hule, Melson et al. (1988) suggested that the formation of the Hule maar had occurred within the last 3000 years. More recently, Soto (1999) reported a second radiocarbon date of $5330 \pm 130{ }^{14} \mathrm{C}$ yr B.P. on a carbonized tree trunk from the same pumaceous flow deposit from Congo dated by Melson et al. (1988). The more recent date reported by Soto (1999) overlaps with the earlier result.

Malavassi et al. (1990) presented four additional radiocarbon dates for eruptions along the Poás volcanic alignment. Carbonized wood samples from the last and penultimate pyroclastic flows that extend beyond the southwest rim of the crater of Volcán Poás yielded radiocarbon ages of $9570 \pm 110{ }^{14} \mathrm{C}$ years and $9840 \pm 75{ }^{14} \mathrm{C}$ years, clearly predating the Congo pyroclastic investigated by Melson et al. (1988). From an exposure near the town of Cariblanco, Malavassi et al. (1990) extracted carbonized wood from an older volcanic deposit from Volcán Congo. That sample yielded a radiocarbon age of $30580 \pm 60{ }^{14} \mathrm{C}$ years. Finally, and most relevant to the present study, Malavassi et al. (1990) extracted a sample of carbonized wood from the last pyroclastic flow from the Hule maar. This sample, which presumably dates the formation of the maar, yielded a radiocarbon age of 2730 $\pm 50{ }^{14} \mathrm{C}$ years.

\section{RECOVERY AND DATING OF LAKE SEDIMENT CORES}

The recovery of cores of lake sediment for paleoecological study from Laguna Hule and nearby Laguna María Aguilar opened another avenue for dating the formation of the Hule maar and later volcanic eruptions in the area. With the help of Costa Rican and U.S. student assistants, I recovered three sediment cores from each lake in July 1988. We cored from an anchored platform assembled from rubber rafts and wood planks, using a PVC tube fitted with a rubber piston for the nearsurface sediments and a square-rod piston corer (Wright et al., 1984) for the deeper sediments.

At Laguna Hule we cored on the northeastern end of the lake. We recovered our first core (Core 1, $3.65 \mathrm{~m}$ long) in $6.9 \mathrm{~m}$ water just off the east side of the peninsula often used as a camping spot by visitors to the lake. We recovered Core 2 (2.62 m long) about $75 \mathrm{~m}$ north of the first core site, closer to the lake outlet in 4.9 $\mathrm{m}$ of water. We recovered Core 3 (3.18 m long) on the opposite side of the peninsula, about 100 $\mathrm{m} \mathrm{SW}$ of its southern tip, in $6.5 \mathrm{~m}$ water. The sediments recovered at each site were dark (Munsell 10 YR 2/1) organic-rich lake sediments. We manually cored the sediments without difficulty until we reached the base of the deposits. At that point we could hear the end of the corer hitting rock or tephra, and could go no deeper. Small amounts of tephra were noted near the bases of Cores 1 and 3 , especially. Distinct horizons of tephra were noted between $0.72-0.74 \mathrm{~m}$ and $0.84-0.85 \mathrm{~m}$ in Cores 2 and 3, respectively, and at $2.24 \mathrm{~m}$ in Core 3. These deposits appear to match up with less distinct horizons of sand-sized particles of possible volcanic origin in the upper $\sim$ meter of Core 1 and lower in the profile of both Core 1 and Core 2. I have not investigated the chemical composition of these tephra layers, but their positions seem to match between cores. They may have come from later eruptions of the intramaaric pyroclastic cone or from another vent within the Poás volcanic alignment. 
Initial radiocarbon dates on bulk sediments from the base of Cores 1 and 3 yielded radiocarbon ages of $7580 \pm 90{ }^{14} \mathrm{C}$ yr B.P. (A$5129)$ and $6910 \pm 90{ }^{14} \mathrm{C}$ yr B.P. $(\beta-34039)$. These dates, clearly inconsistent with the results of Melson et al. (1988) and Malavassi et al. (1990), turned out to have been affected by contamination with "old carbon" - revealed quite clearly when surface sediments yielded a radiocarbon date of $3230 \pm 80{ }^{14} \mathrm{C}$ yr B.P. $(\beta-30430)$, rather than the expected modern date. Evidently, radiocarbon-free carbon dioxide of volcanic origin, or groundwater with an apparent age, is entering the lake and affecting the carbon isotopic composition of aquatic plants and animals that are later incorporated into the lake sediments. Anomalously old radiocarbon dates have been reported for other volcanic regions by Olsson (1986).

These initial bulk sediment dates from Laguna Hule cores were the basis for an earlier estimate (in Horn and Haberyan, 1993) that the maar and lake may have formed 3000-4000 years ago. I derived this estimate by subtracting the age of the surface sediments from the youngest basal radiocarbon date. This method of "correcting" dates affected by old carbon influx has been used by other researchers but can be inaccurate owing to likely variations over time in "old carbon" dating errors (Brubaker, 1975).

\section{AMS RADIOCARBON DATING OF ORGANIC MACROFOSSILS: RESULTS AND DISCUSSION}

A better approach for dating sediments in volcanic lakes is to date individual macrofossils from terrestrial plants not affected by old carbon in the lake system. Advances in accelerator mass spectrometry (AMS) radiocarbon dating now make it possible to routinely date leaves, seeds, and small wood fragments containing as little as $1 \mathrm{mg}$ carbon. Fortunately, such material is present (though not abundant) in the Hule sediments. It is also present in lake sediments from nearby Laguna María Aguilar (10¹8’09”' N, 84¹1'24”; Horn \&
Haberyan, 1993). Located $2 \mathrm{~km}$ ENE of the Hule crater at an elevation of $770 \mathrm{~m}$, this 2.7 ha lake does not occupy a crater but is apparently dammed by a lava flow or volcanic mudflow (G. Soto, pers. comm. 1990). The sediments from this lake also provide information about the eruptive history of the Hule explosion crater.

Table 1 presents the results of AMS radiocarbon dating of small organic samples from the Hule and María Aguilar sediment cores, together with the dates on wood from the Congo and Hule pyroclastic flows dated by Melson et al. (1988), Malavassi et al. (1990) and Soto (1999). The table lists the conventional radiocarbon dates, and also the calendar age ranges obtained by using revision 4.1.2 of the CALIB radiocarbon age calibration program of Stuiver and Reimer (1993) and the dataset of Stuiver et al. (1998). The one-sigma ranges correspond to the $68 \%$ confidence interval for the calendar ages, and the two-sigma ranges correspond to the $95 \%$ confidence interval.

The first of the AMS dates I obtained for Hule and María Aguilar lake sediments was for a small wood fragment found at $2.66 \mathrm{~m}$ in Laguna Hule Core 3. The resulting age of $3080 \pm 70{ }^{14} \mathrm{C}$ yr B.P. was consistent with the estimate of Melson et al. (1988) that the Hule maar had formed about 3000 years ago, but was older, and thus inconsistent, with the date that Malavassi et al. (1990) reported for the ultimate pyroclastic flow in the Hule maar. As with all wood samples, the possibility existed that the small wood fragment dated already might have been several hundreds of years old at the time it was deposited in the sediments, having been part of the inner wood of an old tree, or having been preserved for some time elsewhere in the landscape before reaching the lake. For this reason, when additional resources became available for AMS work on the Hule cores I chose to concentrate on the dating of fragments of leaves from terrestrial plants. Leaves are short-lived and generally decay quickly in tropical environments, such that the age of a leaf is a very good indicator of the age of the sediments that surround it. As it turns out, dates on leaves in sediments from Laguna Hule and Laguna María Aguilar provide the best 
TABLE 1

Radiocarbon dates from Hule and Congo volcanic deposits and lake sediments from Laguna Hule and Laguna María Aguilar

\begin{tabular}{|c|c|c|c|c|c|}
\hline $\begin{array}{l}\text { Reference, or } \\
\text { Lab Number for } \\
\text { Horn AMS } \\
\text { samples }\end{array}$ & $\begin{array}{l}\text { Sample and } \\
\text { Context }\end{array}$ & $\begin{array}{l}\text { Radiocarbon Age } \\
\text { 14C yr B.P. }\end{array}$ & $\begin{array}{c}\text { Calibrated Age } \\
\text { cal yr B.P }\end{array}$ & $\begin{array}{l}\text { Calibrated Age } \\
\text { Range (1 s). } \\
\text { cal yr B.P }\end{array}$ & $\begin{array}{l}\text { Calibrated Age } \\
\text { Range (2 s) } \\
\text { cal yr B.P. }\end{array}$ \\
\hline $\begin{array}{l}\text { Melson et al. } \\
\text { (1988) }\end{array}$ & $\begin{array}{l}\text { Wood in Congo } \\
\text { pyroclastic } \\
\text { deposit }\end{array}$ & $5140 \pm 110$ & 5910 & $5990-5750$ & $6170-5620$ \\
\hline Soto (1999) & $\begin{array}{l}\text { Wood in Congo } \\
\text { pyroclastic } \\
\text { deposit }\end{array}$ & $5330 \pm 130$ & $\begin{array}{l}6170,6140, \\
6110,6070, \\
6060,6010, \\
6000\end{array}$ & $6280-5930$ & $6400-5760$ \\
\hline $\begin{array}{l}\text { Malavassi et al. } \\
\text { (1990) }\end{array}$ & $\begin{array}{l}\text { Wood in Hule } \\
\text { pyroclastic } \\
\text { deposit }\end{array}$ & $2730 \pm 50$ & $\begin{array}{l}2841,2828, \\
2787\end{array}$ & $2870-2780$ & $2950-2750$ \\
\hline$\beta-56233$ & $\begin{array}{l}\text { Wood at } 2.66 \mathrm{~m} \\
\text { in Hule Core } 3\end{array}$ & $3080 \pm 70$ & $\begin{array}{l}3330,3280, \\
3270\end{array}$ & $3380-3170$ & $3450-3080$ \\
\hline B -73925 & $\begin{array}{l}\text { Leaf at } 1.45 \mathrm{~m} \\
\text { in Hule Core } 3\end{array}$ & $1250 \pm 60$ & 1180 & $1260-1070$ & $1290-1000$ \\
\hline ß-73926 & $\begin{array}{l}\text { Leaf at } 2.94 \mathrm{~m} \\
\text { in Hule Core } 3\end{array}$ & $2230 \pm 60$ & $\begin{array}{l}2310,2240, \\
2210,2190, \\
2180\end{array}$ & $2340-2150$ & $2350-2070$ \\
\hline OS-4412 & $\begin{array}{l}\text { Leaf above ash } \\
\text { in María Aguilar } \\
\text { Core } 1\end{array}$ & $2520 \pm 30$ & $\begin{array}{l}2712,2625, \\
2623\end{array}$ & $2736-2496$ & $2744-2471$ \\
\hline$\beta-56234$ & $\begin{array}{l}\text { Small wood } \\
\text { fragments at } \\
\text { base of María } \\
\text { Aguilar Core } 3\end{array}$ & $2610 \pm 70$ & 2750 & $2780-2730$ & $2850-2490$ \\
\hline
\end{tabular}

Notes:

AMS analyses for Horn's samples were performed by Beta Analytic Laboratory (_ numbers) and by the National Ocean Sciences AMS facility (OS numbers). Errors estimate 68\% (1 s) and 95\% (2 s) probability. Calibrations were determined using version 4.1.2 of the CALIB radiocarbon age calibration system (Stuiver and Reimer 1993) and are based on the dataset of Stuiver et al. (1998). Following Stuiver and Reimer (1993), calibrated ages and age ranges for radiocarbon dates with standard deviations $\geq 50$ years are rounded to the nearest 10 years.

evidence from the lake cores of the eruptive history of the Hule maar.

I have obtained AMS radiocarbon dates on two leaf samples from Laguna Hule Core 3. The uppermost sample (1.45 $\mathrm{m}$ depth), positioned about midway between the two tephra layers in the core, yielded a radiocarbon age of $1250 \pm 60$ ${ }^{14} \mathrm{C}$ yr B.P. (B-73925). The second AMS sample
(2.94 $\mathrm{m}$ depth) came from just $0.24 \mathrm{~m}$ above the base of the core. The resulting age of $2230 \pm 60$ yr ${ }^{14} \mathrm{C}$ (B-73926) indicates that a lake existed in the crater and at the core site by this time. Extrapolating from the sedimentation rate between the two horizons from which leaves were extracted and dated provides an estimate of the time potentially represented by the lowest 
$0.24 \mathrm{~m}$ of sediment in Core 3 . The two dated horizons are separated by $1.49 \mathrm{~m}$ of sediment and 980 radiocarbon years, indicating a sedimentation rate of $0.0015 \mathrm{~m} /$ radiocarbon year; dividing $0.24 \mathrm{~m}$ by this rate suggests that the lowest 0.24 $\mathrm{m}$ represents 160 radiocarbon years. Adding this number to the lower date more tightly constrains the formation of the lake by suggesting that lake sediments began to be deposited by approximately 2400 radiocarbon years ago. Performing the same calculation based on the calibrated calendar ages for the two leaves (using the midpoint for the lower leaf, which calibrates to five possible calendar ages), results in a sedimentation rate of $0.0014 \mathrm{~m} /$ calendar year, and an age estimate of approximately 2420 calendar years for the base of the core. If sediment accumulated more slowly during the initiation of the lake than at later times, the bottom of the core is probably older; however, these estimates for the age of the base of the sediment core together with the date by Malavassi et al. (1990) on the Hule pyroclastics of $2730 \pm 50{ }^{14} \mathrm{C}$ yr B.P. (2950-2750 calendar years B.P.) surely bracket the formation of the maar and lake.

AMS dates on leaf fragments and small pieces of wood in sediment cores from Laguna María Aguilar provide further information on the timing of the formation of the Hule crater. From our first core site near the western edge of Laguna María Aguilar we recovered a $7.4 \mathrm{~m}$ long core that penetrated an approximately $0.5 \mathrm{~m}$ thick ash layer that most likely came from the Hule maar. Core 3 from the center of the lake bottomed out at a resistant layer that appears to be the same or related volcanic deposit. Core 2 also seems to have been stopped by this deposit, though the stratigraphy of this core has not been studied in as much detail.

A leaf fragment directly above the ash in María Aguilar Core 1 yielded a radiocarbon age of $2520 \pm 30{ }^{14}$ C yr B.P. (OS-4412), and small wood fragments at the base of María Aguilar Core 3 yielded a radiocarbon age of $2610 \pm 70{ }^{14} \mathrm{C}$ yr B.P. (B-56234). Given that wood can be several centuries old at the time it is incorporated into a geological deposit, the date on the leaf overlying the ash in Laguna María Aguilar Core 1 is probably a better estimate of the age of the ash. The radiocarbon date of $2520 \pm 30 \mathrm{yr}$ B.P on the leaf more closely matches the estimated date of $\sim 2400{ }^{14} \mathrm{C}$ years B.P. for the beginning of organic sedimentation at Core Site 3 in Laguna Hule than does the Malavassi date of $2730 \pm 50{ }^{14} \mathrm{C}$ yr B.P. on wood from the Hule pyroclastic deposit. Assuming that the ash deposit in the Laguna María Aguilar core is indeed from the explosion of the Laguna Hule crater, this difference in radiocarbon dates may simply reflect the nature of the material dated (leaf vs. wood). However, it could also indicate that the formation of the Hule maar was not a single and simple event but involved successive eruptions over a period of perhaps a few centuries.

The age discrepancy is in any case minor, and disappears or almost does when the radiocarbon dates are calibrated (Table 1). The two-sigma calibrated age ranges for the wood fragments from the base of Laguna María Aguilar Core 3 and the leaf overlying the ash in Laguna María Aguilar Core 1 overlap, and the one-sigma calibrated ranges almost do. The one- and two-sigma calibrated age ranges for the basal wood fragments also overlap with the calibrated age ranges for the wood from the Hule pyroclastic deposit dated by Malvassi et al. (1990), and the two-sigma calibrated age range for the leaf overlying the ash at Laguna María Aguilar is separated from the latter by only nine years. None of these dates overlap at the one- or two-sigma level with the leaf date from the Laguna Hule core, but they should not be expected to as that leaf is separated from the base of the core by 0.24 $\mathrm{m}$ of lake sediment that likely represents one to several centuries of accumulation.

The AMS radiocarbon dates on macrofossils from the Hule and María Aguilar complement and extend the results of radiocarbon dating by Melson et al. (1988), Malavassi et al. (1990), and Soto (1999) on wood in tephra deposits exposed in roadcuts near Laguna Hule. The new dates indicate that the Hule maar formed 2780-2490 radiocarbon years B.P., which corresponds to calibrated calendar age ranges of 2870-2496 (1-sigma) or 2950-2471 (2-sigma) cal. years B.P. Organic sedimentation began within a few centuries of maar formation, indicating the formation of Laguna Hule. 
At least twice since then, a volcanic eruption within or near the crater deposited tephra that was preserved as a distinct layer in sediments recovered at Core Site 3. These eruptions were possibly from the intramaaric subsidiary cone. Extrapolating from sedimentation rates calculated from the two AMS radiocarbon dates on leaves in this core suggests that the earlier eruption occurred about $1740 \mathrm{cal}$. years B.P. and the more recent eruption occurred about 670 cal. years B.P.

For the indigenous people who then occupied Costa Rica, the formation of the Hule explosion crater must have been quite an event. Preliminary archaeological research at La Paila, a site located $7 \mathrm{~km}$ west of the Hule crater, suggests a possible abandonment of the area at about the time of the Hule eruption. The site has yet to be excavated, but surface collections indicate that it was a fairly early habitation site. Ceramic artefacts suggest that the site was occupied between about 1500-500 B.C., or roughly 3450-2450 years B.P. (M. Sánchez, pers. comm. 1999). The explosion of the Hule crater may explain why no artefacts from more recent periods have been found at the La Paila site. Pollen analysis of sediment cores from Laguna María Aguilar indicate abandonment of this area at approximately the same time. That is, pollen spectra in sediments below the ash layer in Core 3 from the lake show evidence of human presence, but sediments above the ash layer do not (S. Horn and J. Rodgers, unpublished data).

The documentation of the history of volcanic events at Laguna Hule and their impacts on prehistoric peoples contributes to the assessment of modern-day volcanic hazards in Costa Rica (Malavassi et al. 1990). It would be interesting in this regard to determine how the geologic recency of volcanic events in and near Laguna Hule compares with the timing of events at the Río Cuarto maar, located about $6 \mathrm{~km}$ north of Laguna Hule along the same volcanic alignment (Fig. 2). The formation of this crater has yet to be dated. Given the great depth of the Laguna del Río Cuarto (66 m; Horn \& Haberyan 1993), coring lake sediments would present a tremendous technical challenge; a more practical approach would be to search for datable organics in deposits generated by the eruption of this crater. Alvarado (1989) described exposures of pyroclastic deposits that may be associated with the formation of the Río Cuarto maar, and conjectured that the feature may be of rather recent age. It is possible that this maar is younger than the Hule maar, and that some of the tephra in the Laguna Hule sediment cores might record the explosive origin of the Río Cuarto maar rather than eruptions of the intramaaric cone. Northward dispersion of tephra from Laguna Río Cuarto would be favored by the dominant trade winds; however, explosions from other volcanic vents in the area, including those of Volcán Poás, might conceivably also be recorded in Hule lake sediments.

\section{ACKNOWLEDGEMENTS}

The recovery and dating of the Laguna Hule and Laguna María Aguilar sediment cores were supported by grants from the University of Tennessee, the National Geographic Society, the Association of American Geographers, and the National Science Foundation (SES-911588). For field and logistical assistance in Costa Rica I thank Gilbert Vargas, Carolyn Hall, Douglas Baird, Jr., Isabel Avendaño, Jairo Mora, Olger Duran, and Carlos Zuñiga. Edward Gray collaborated in the description of the sediments of Hule Core 3, as part of related work on the pollen stratigraphy of the core that will be presented elsewhere. I thank the Costa Rican government and several private landowners for granting access to Laguna Hule and Laguna María Aguilar and permission to recover sediment cores.

\section{REFERENCES}

ALVARADO I., G.E., 1989: Los Volcanes de Costa Rica. - 175 págs.; EUNED, San José, Costa Rica.

BRUBAKER, L., 1975: Postglacial forest patterns associated with till and outwash in northcentral upper Michigan. - Quaternary Res. 5: 499-527. 
HABERYAN, K. A., \& HORN, S. P. [in press]: Physical and chemical characteristics of seven volcanic lakes in Costa Rica. Brenesia, 51.

HORN, S. P. \& HABERYAN, K. A., 1993: Physical and chemical properties of Costa Rican lakes. - National Geogr. Res. and Explor. 9: 86-103.

MALAVASSI, E., GILL, J. B., \& TRIMBLE, D., 1990: Nuevas dataciones radiométricas del alineamiento volcánico de Poás (Costa Rica): contribución a la evaluación de peligros volcánicos.- Programas y resumenes de ponencias, VII Congreso Geológico de America Central, p. 37.

MELSON, W. G., SAENZ R., R., BARQUERO H., J., \& FERNANDEZ S., E., 1988: Edad relativa de las erupciones del Cerro Congo y Laguna Hule. - Bol. Vulcanología, 19: 8-10.

OLSSON, I.U., 1986: Radiometric dating. - In: BERGLUND, B. E., (ed.): Handbook of Holocene palaeoecology and palaeohydrology: 273-312; John Wiley, New York.

SOTO, G.J., 1990: Consideraciones volcanológicas y tectónicas preliminares del área de Laguna Hule. - 14 págs. Instituto Costarricense de Electricidad, San José.
SOTO, G., 1999: Geología regional de la hoja Poás (1:50 000).- En: ALVARADO, G. E. \& MADRIGAL, L. A. (eds.): Estudio geológico - geotécnico de avance a la factibilidad del P.H. Laguna Hule: 15-45; Instituto Costarricense de Electricidad, San José [informe interno].

STUIVER, M., \& REIMER, P. J., 1993: Extended C-14 database and revised Calib $3.0 \mathrm{C}-14$ age calibration program. Radiocarbon, 35: 215-230

STUIVER, M., REIMER, P. J., BARD, E., BECK, J. W., BURR, G. S., HUGHEN, K. A., KROMER, B., McCORMAC, G., VAN DER PLICHT, J., \& SPURK, M., 1998: INTCAL98 radiocarbon age calibration, 24,000-0 BP. - Radiocarbon, 40: 10411083.

UMANA, G., HABERYAN, K. A., \& HORN, S. P., 1999: Limnology in Costa Rica. - In: WETZEL, R. G. \& GOPAL, B. (eds.): Limnology in developing countries vol. 2: 33-62; New Delhi International Scientific Publications, New Delhi.

WRIGHT, H. E., Jr., MANN, D. H., \& GLASER, P. H., 1984: Piston corers for peat and lake sediments. - Ecology, 65: 657-659. 